\title{
ЧИННИКИ ПІДГОТОВКИ МАЙБУТНІХ СОЦІАЛЬНИХ ПРАЦІВНИКІВ ДО ПРОФЕСІЙНОЇ ДІЯЛЬНОСТІ В СІМ'Ї ЯК ОСНОВНОМУ АГЕНТІ СОЦІАЛІЗАЦІЇ ДІТЕЙ-СИРІТ ТА ДІТЕЙ, ПОЗБАВЛЕНИХ БАТЬКІВСЬКОГО ПІКЛУВАННЯ
}

\author{
OKSANA HALAN, Postgraduate student of Regional \\ Humanitarian and Pedagogical Academy of Taras \\ Shevchenko in Kremenets, Ukraine
}

\section{FACTORS OF PREPARATION OF FUTURE SOCIAL WORKERS FOR PROFESSIONAL ACTIVITY IN THE FAMILY AS THE MAIN AGENT OF SOCIALIZATION OF ORPHAN CHILDREN AND CHILDREN DEPRIVED OF PARENTAL CARE}

\begin{abstract}
В умовах реформування установ для дітей-сиріт та дітей, позбавлених батьківського піклування, в Україні виникла необхідність переосмислення особливостей підготовки майбутніх соціальних працівників до професійної діяльності у закладах вищої освіти. Особливу увагу вчених зосереджено на питанні готовності фахівців до соціалізації знедолених дітей у сім'ях (біологічних чи набутих). Нами розглянуто та проаналізовано основні чинники, які сприятимуть якісній підготовці соціальних працівників до роботи із сім'єю як незамінною та первинною ланкою, що забезпечує успішне "входження" дітей-сиріт та дітей, позбавлених батьківського піклування, у соціум. На основі проведених теоретичного аналізу та практичної роботи ми довели, що використання новітніх технологій сприятиме професійній діяльності із суб'єктами деінституціоналізації.
\end{abstract}

Ключові слова: соціальна робота, соціальний працівник, сім'я (біологічна та набута), діти-сироти, діти, позбавлені батьківського піклування, соціалізація.

Summary. In the context of reforming institutions for orphans and children deprived of parental care in Ukraine, there was a need to rethink the features of preparing future social workers for professional activity in Higher Education Establishments. Special attention is paid to the willingness of workers to socialize

(c) О. Галан with children in families (biological or acquired). We have analyzed the main factors that will contribute to successful preparation of social workers for the work with the family that ensures the successful "entry" of orphans and children deprived of parental care in society. Based on theoretical analysis and practical work, we have shown that the use of the latest technologies will facilitate the professional activity.

Key words: social work, social worker, family (biological and acquired), orphans, children deprived of parental care, socialization.

Мета: з'ясувати чинники професійної підготовки майбугніх соціальних працівників до соціалізації дітей-сиріт та дітей, позбавлених батьківського піклування в біологічних чи набутих сім'ях; довести позитивний вплив новітніх технологій на означений процес.

Постановка проблеми в загальному вигляді. За останні роки турбота про благополуччя дітей і збереження сімейного оточення для них постало важливим стратегічним завданням перед нашою державою. Саме на це спрямоване вдосконалення законодавчої бази, основними векторами розвитку якої є підтримка сімей, які знаходяться у складних життєвих обставинах, а також реформування державної системи влаштування дітей-сиріт та дітей, позбавлених батьківського піклування, з поступовою їх реінтеграцією у біологічні чи набуті сім'ї.
Одним з основних пріоритетів національної політики держави є попередження найбільш актуальних загроз вразливої категорії дитячого населення. До них відносимо негативний вплив позасімейної соціалізації на соціальну поведінку та адаптацію сиріт у сучасне суспільство (Указ Президента Украӥни "Про деякі питання.., 2019).

Згідно з Проєктом Концепції державної політики щодо досягнення цілі "Кожна дитина зростає та виховується в родинах або в умовах, максимально наближених до сімейних, у благополучному, доброзичливому та безпечному середовищі, де дбають про потреби та інтереси дітей". Сьогодні кількість дітей, котрі перебувають у закладах інституційного догляду та виховання, утричі більша, ніж у країнах $\mathrm{CC}$, а випускники інтернатів у переважній більшості випадків потребують постійної підтримки держави; 90\% 3 них не готові до життя в соціумі. $92 \%$ дітей, котрі перебувають в інтернатах, мають батьків, та близько $30 \%$ можуть повернутися у сім'ї. Щороку близько 10 тис. дітей залишаються без батьківського піклування, зокрема, через безвідповідальне ставлення рідних до виконання своїх обов'язків, уживання алкоголю, наркотичних засобів, жорстоке поводження 3 дитиною, інші сімейні скрути (Програма діяльності.., 2019).

Таким чином, гуманістична спрямованість державної соціальної політики на виховання дітей-сиріт та дітей, 
позбавлених батьківського піклування, у сім'ї як основному агенті соціалізації передбачає залучення їх у ті процеси, що сприятимуть формуванню всебічно розвиненої особистості із стійкою моральною та світоглядною установкою.

Аналіз досліджень і публікацій. Наукова спільнота також не залишається осторонь цієї проблематики. У сучасному суспільстві загалом та в освітньому просторі зокрема як ніколи актуальними стали наукові напрацювання педагогів-гуманістів, що пройшли випробування часом: Г. Гмейнера, Я. Корчака, П. Лесгафта, I. Песталоцці, В. Сухомлинського та інших. Їх праці довели, що сім'я - це те виховне середовище, що сприяє гармонійному розвитку дітей, їх успішній соціалізації та соціально особистісному становленню. Саме в ній започатковуються і розширюються світоглядне бачення, морально-естетичні ідеали і смаки, норми поведінки, трудові навички, ціннісні орієнтації, тобто те, що згодом становитиме соціальну сутність дітей.

Наразі багаторічний досвід виховання осиротілих дітей у державних інституціях показав, що їх вихованці виявились не готовими до життя у соціумі. Система так званого "закритого" виховного середовища відсторонила вразливу категорію дітей від активної взаємодії з навколишнім світом, у результаті чого вони не змогли своєчасно та в повному обсязі отримати необхідні соціальні знання, уміння та навички, тобто соціальні компетенції. Ця ситуація викликала необхідність активізації у сучасному суспільстві сімейних форм влаштування дітей-сиріт та дітей, позбавлених батьківського піклування. Водночас перед закладами вищої освіти (далі 3ВО) України постало завдання вдосконалення професійної підготовки майбутніх соціальних працівників відповідно до вимог сьогодення.

Відтак соціалізацію особистості і значення в цьому процесі альтернативних форм виховання дітей досліджували Г. Бевз, І. Пєша та інші. Вагомий внесок зробила I. Пєша, яка довела, що соціальне становлення особистості залежить від іiі перебування у певному соціумі, у якому вона розвивається, набуваючи певних якостей, що поступово інтерпоризуються, засвоюються, усталюються (незалежно від того, позитивні ці якості чи негативні). Це відбувається упроцесі формування самосвідомості індивіда, зас- воєння досвіду і цінностей суспільства - процесі соціалізації, основою формування і розвитку особистості дитини якого $\epsilon$, у першу чергу, сімейне оточення, умови сімейного виховання (Пєша, 2000).

Окремі питання змісту та форм соціальної роботи із сім'єю як провідним інститутом соціалізації особистості досліджували Т. Алєксєєнко, I. Трубавіна, Т. Кравченко та інші. Зокрема, Т. Алєксєєнко особливу увагу приділяе проблемі оптимізації умов соціалізації особистості у її найближчому оточенні, з перших років життя дитини. 3 цих міркувань у Концепції соціально-педагогічного патронату молодої сім'ї її розглядають 3 позиції дієвого механізму створення цілісного виховуючого середовища на основі активізації громади 3 метою профілактики девіантної поведінки дітей і молоді, зміцнення інституту сім'ї, підвищення ефективності соціальної роботи за місцем проживання, об'єднання зусиль усіх агентів соціалізації незалежно від їх секторальної стратифікації. Тому особливі вимоги вчена ставить перед фахівцями, котрі здійснюють професійну діяльність окресленого напряму. Т. Алєксєєнко відзначає, що у цьому процесі відбуваються зміни в усіх учасників суб'єктсуб'єктної і суб'єкт-об'єктної взаємодії, а також умов самої діяльності: набуваються нові знання, соціальний і професійний досвід, зростає ступінь самостійності особистості, іiі здатність контролювати своє життя та ефективно вирішувати назрілі проблеми; оптимізуються умови життєдіяльності, у яких полегшуються адаптація та індивідуалізація.

У контексті нашого дослідження одним з провідних принципів соціальної роботи науковиця виокремлює принцип компетентності:

• професійну підготовленість фахівця;

- уміння обирати оптимальні варіанти соціальної роботи і забезпечувати їх кваліфіковану реалізацію;

- досвід професійної діяльності (Алєксєєнко, 2007).

Проте на сучасному етапі розвитку освіти залишається недосконалою змістова сторона підготовки соціальних працівників до професійної діяльності $з$ дітьми-сиротами та дітьми, позбавленими батьківського піклування, у якій вбачаємо акцентування на сім'ї як основному агенті соціалізації, а принцип тимчасового розміщення дітей в установу чи патронат повинен працювати лише до моменту знаходження їм постійної сім'ї.

Виклад основного матеріалу дослідження. Педагогічна наука ставить чіткі вимоги до особистості майбутнього соціального працівника в Україні. 3-поміж основних виокремлюємо соціальну гідність, стійку громадянську позицію, високу моральність, свідомість, творчий потенціал тощо. Усі ці якості вкрай необхідні для повноцінного життя у соціумі, впливають на його якість та створюють передумови для творчого перетворення навколишнього світу. На нашу думку, лише такий фахівець здатний на високопрофесійному рівні здійснювати професійну діяльність, передати ці якості осиротілим дітям, які внаслідок складних життевих обставин не в змозі самостійно протистояти викликам долі.

Тому перед соціальними працівниками вперше постало питання допомогти дітям-сиротам та дітям, позбавленим батьківського піклування, інтегруватись у біологічні чи набуті сім'ї шляхом співпраці всіх суб'єктів цього процесу з метою створення умов для виховання повноцінної соціально адаптованої особистості. Проте відсутність загальноприйнятої універсальної моделі професійної освіти соціального працівника з виділенням конкретної сфери діяльності призводить до неготовності фахівців здійснювати корекційно-виховні завдання, спрямовані на становлення чітких життєвих перспектив знедолених дітей.

Поділяємо думку О. Бобак, котра стверджує, що професійну підготовку соціального працівника необхідно зорієнтовувати на принцип самозабезпечення сім'ї, тобто пошук і стимуляцію її внутрішніх резервів, які допоможуть вирішити власні проблеми (Бобак, 2012). Вважаємо такий діяльнісний підхід до подолання життєвих труднощів найбільш оптимальним, оскільки активізація особистісного потенціалу всіх членів сім'ї здатна забезпечити позитивну соціалізацію дітей-сиріт та дітей, позбавлених батьківського піклування.

Дослідниця В. Рюль зазначає, що моделі і технології самостійного долання життєвих труднощів повинні відновлювати уграчені соціальні взаємозв'язки між дитиною та соціальним оточенням, що автоматично мобілізує як внутрішні, так і зовнішні ресурси особистості. Це особливо актуально за наявності загостреного відчуття самотності, яке сигналізує про пору- 
шення природних зв'язків у соціальній мережі. Тому в більшості випадків для реалізації таких моделей необхідна соціальна підтримка й допомога; при цьому дитина, у першу чергу, розраховує на підтримку батьків, особливо за умови їх включеності в необхідність долання дитячих труднощів (Рюль, 2013).

Чинне місце при виникненні специфічних життєвих ситуацій у процесі соціалізації дітей-сиріт та дітей, позбавлених батьківського піклування, у сім'ї відводиться соціальним працівникам, котрі шляхом надання соціальної допомоги здійснюють корекцію такого процесу. Тому в рамках концептуального підходу "допомога для самодопомоги", запропонованого I. Трубавіною, основними чинниками створення соціальними працівниками корекційно-виховного середовища в біологічних чи набутих сім'ях виділяємо:

1. Доброзичливі стосунки між усіма суб'єктами деінституціоналізації та створення необхідних умов для довірливого мікроклімату в новому сімейному оточенні дитини.

На нашу думку, позитивна взаємодія всіх учасників процесузбільшуватиме впевненість дітей щодо можливостей вирішення будь-якої проблеми, розвиватиме такі позитивні якості, як цілеспрямованість, наполегливість, відповідальність, толерантність тощо. Для цього соціальним працівникам необхідно використовувати певні форми і методи:

- бесіди з батьками та дітьми щодо проблем, які виникають у процесі виховання у сім'ї;

- залучення до благодійних соціальних проєктів (свято сім'ї, конкурс "Найкраща прийомна сім'я", масових культурних заходів, що організовуються місцевою радою чи територіальною громадою тощо).

Це дає змогу вступати дітям-сиротам та дітям, позбавленим батьківського піклування, у різноманітні взаємодії $з$ навколишнім світом, допомагає їм соціалізуватись, а оточуючим позитивно налаштовуватись на взаємини 3 такими дітьми.

2. Достатній рівень педагогічної культури всіх учасників соціалізаційного процесу. Це передусім, педагогічні знання та педагогічні здібності соціальних працівників, які допомагають зрозуміти потреби дитини, усвідомити шляхи впливу на неї, реально оцінити ту чи іншу ситуацію, скорегувати поведінку дитини. Соціальна робота повинна супроводжуватись тактовністю щодо осиротілих дітей, прийомних батьків, вихователів, опікунів та ін. 3 використанням консультацій, ненав'язливих бесід, оскільки непорозуміння усередині родини виникають саме через недостатній рівень педагогічної культури.

Академік М. Стельмахович у своїй праці "Теорія і практика українського національного виховання" зазначав, що "взаємини батьків між собою та їх ставлення до дітей ? незамінима практична школа батьківства й материнства для підростаючого покоління" (Стельмахович, 1996).

3. Усвідомлення власної соціальної ролі.

У першу чергу, майбутні соціальні працівники повинні чітко розуміти свою соціальну роль у професійній діяльності з осиротілими дітьми. Подруге, фахівці мають доступно донести до дітей-сиріт та дітей, позбавлених батьківського піклування, що сім'я $\epsilon$ фундаментом здорового суспільства, запорукою їх гармонійного "входження" у соціум. Водночас необхідно розвивати в дітей відчуття єдності із сім'єю, причетності до загальних справ родини. По-трете, члени сім'ї також повинні усвідомлювати те, що вони виконують найважливішу соціальну роль у своєму житті, виховуючи майбутніх громадян, та своїм позитивним прикладом формують успішних членів суспільства.

4. Системна педагогічна робота соціальних працівників із сім'єю з формування соціальних компетенцій дітей-сиріт та дітей, позбавлених батьківського піклування, кінцевим результатом якої $\epsilon$ їх готовність до самостійної життєдіяльності.

Науковець А. Биков виокремлює такі їі різновиди:

- соціальна готовність (сформованість навичок міжособистісного спілкування, колективної діяльності, соціально-побутової орієнтації, організації самостійного життя і діяльності, адаптація до свого соціального статусу);

- трудова готовність (сформованість загальних життєвих умінь і навичок, готовність до праці в побуті, у домашньому господарстві, професійне самовизначення, підготовка до майбутньої професійної діяльності);

- морально-вольова (психологічна) готовність (самооцінка, почуття самоповаги, вольова організація особистості, психологічна готовність до праці в умовах ринкових відносин);
- фізична готовність (формування здорового способу життя, відсутність шкідливих звичок, розвиток фізичних якостей, що забезпечують адаптацію до праці, різноманітних видів діяльності) (Быков, 2014).

Важливою умовою успішності системної педагогічної роботи соціальних працівників виступає посилення дії принципу відкритості до навколишнього світу, що полягає у розвитку почуття довіри до оточуючих, комунікативних навичок, ціннісно-смислових установок тощо. Усі чинники взаємопов'язані та взаємообумовлені і лише у тісній взаємодії сприятимуть самореалізації дітей-сиріт та дітей, позбавлених батьківського піклування, у соціумі, їх перетворення на самодостатній соціальний організм.

3 метою перевірки ефективності використання означених чинників у професійній підготовці майбутніх соціальних працівників до соціалізації дітей-сиріт та дітей, позбавлених батьківського піклування, у сім'ї нами було проведено експериментальнодослідницьку роботу зі студентами 31 "Соціальна робота" та 41 "Соціальна робота" груп Кременецької обласної гуманітарно-педагогічної академії ім. Тараса Шевченка. Основна орієнтація спрямовувалась на науково-експериментальний досвід, впроваджений I. Скуратовською та М. Нікуліною в установах для осиротілих дітей (Бblков, 2014). Об'єктом дослідження виступив освітній процес, предметом діяльності-ситуація соціального розвитку осиротілих дітей у сім'ї як системі їх взаємин з навколишнім світом. Ціллю професійної підготовки майбутніх соціальних працівників стало забезпечення умов для розвитку означених вище чинників 3 використанням новітніх технологій.

Експериментальна робота була побудована таким чином, що на I етапі визначалась головна мета - становлення соціального працівника як експериментатора, котрий володіє професійною компетентністю, креативністю, готового до створення та застосування інновацій у процесі виховання і соціального розвитку дітейсиріт та дітей, позбавлених батьківського піклування. Проведена робота передбачала діагностику рівня готовності майбутніх соціальних працівників до експериментальної діяльності шляхом анкетування "Місце інновацій у моїй професійній діяльності". Аналіз анкетних даних з питань раціонального використання часу і задово- 
леності навчанням в експериментальних умовах на початковому етапі показав невисокі результати (63\%). Поширеною відповіддю серед студентів була "вважають інновацію додатковим навантаженням", що потребує зайвого використання особистого часу та сил. На II та III етапах робота спрямовувалась на підтримку достатнього рівня мотивації, стимулювання пізнавальної активності та активізацію творчих ресурсів. Хорошим стимулом стало використання таких форм, як колективне вирішення проблемних ситуацій (позиційний аналіз ситуацій, метод "дорощування" у пошуку рішень, групова дискусія з найбільш важливих питань, спільні творчі справи і втілення проєктної діяльності (конкурс проєктів). Упродовж усього періоду експерименту акцентування здійснювалось на розширення знань про значимість і актуальність проблеми соціалізації дітей-сиріт та дітей, позбавлених батьківського піклування, у сім'ї, створення колективу однодумців для ефективної екпериментальної діяльності. Отримані позитивні результати переконали в тому, що повторне анкетування виявило високий поріг рівня готовності майбутніх соціальних працівників до використання інновацій у професійній діяльності 92\% (Быков, 2014).

Висновки та перспективи подальших досліджень. Теоретичний аналіз літератури, узагальнення експериментальної діяльності показали, що проблема формування готовності майбутніх соціальних працівників до соціалізації дітей-сиріт та дітей, позбавлених батьківського піклування, у сім'ї стала соціально значимою саме в сучасних умовах переосмислення освітнього процесу у ЗВО України. Систематизація та узагальнення кількісних і якісних характеристик, отриманих у ході експериментальної роботи, надали змогу виявлення рівня готовності фахівців до означеної діяльності. Одним 3 напрямів професійної підготовки фахівців ми виокремили застосування новітніх технологій як можливість побачити свою майбутню діяльність у динаміці, усвідомити значимість засвоєння фундаментальних знань, отримати досвід інтенсивної практичної роботи. Аналіз експериментального дослідження потвердив необхідність доповнення традиційної системи підготовки соціальних праці-

\section{вників новітніми технологіями.}

Проведена нами робота не є вичерпною $з$ усіх аспектів проблеми. Подальшими напрямами дослідження вбачаємо активне включення студентів у волонтерську діяльність 3 метою формування усвідомленої громадянської позиції, спрямованої на діяльнісну допомогу дітям-сиротам та дітям, позбавленим батьківського піклування, шляхом взаємодії з центрами соціальної допомоги та підтримки дітей.

\section{СПИСОК ЛІТЕРАТУРИ}

Алєксєєнко, Т. Ф. (2007). Сойіалізачія особистості: можливості й ризики. Київ : Пед. думка.

Быков, А. К., Волохатова, В. М. (2014). Формирование социальных компетенций, готовности к самостоятельному жизнеустройству у воспитанников детских интернатных учреждений. Москва : ИПК ДСЗН.

Бобак, О. (2012). Підготовка соціального педагога до організації роботи з сім'єю як первинного інституту соціалізації дитини. Актуальні питання гуманітарних наук, 3, 152-158.

Пєша, I. В. (2000). Соціальне становлення дітей в дитячих будинках сімейного типу. (Автореф. дис. ... канд. пед. наук. Національний пед. унт ім. М. П. Драгоманова, Київ.

Кожна дитина зростає та виховується в родинах або в умовах, максимально наближених до сімейних, у благополучному, доброзичливому та безпечному середовищі, де дбають про потреби та інтереси дітей. Програма діяльності Кабінету Міністрів України (2019). Взято 3 https:// program.kmu.gov.ua/meta/kozna-ditinazrostae-ta-vihovuetsa-v-rodinah-abo-vumovah-maksimalno-nablizenih-dosimejnih-u-blag opolucnomudobroziclivomu-ta-bezpecnomuseredovisi-de-dbaut-pro-potrebi-tainteresi-ditej

Рюль, В. О. (2013). Соціалізація дітей трудових мігрантів Закарпаття. Ужгород : Видавництво ФОП Бреза A.E.

Стельмахович, М. Г. (1996). Теорія і практика українського національного виховання. Івано-Франківськ : Лілея-НВ.

Про деякі питання забезпечення прав та законних інтересів дітей-сиріт, дітей, позбавлених батьківського піклування, розвитку та підтримки сімейних форм виховання дітей. Указ Президента України (2019). Взято 3 https://zakon.rada.gov.ua/go/721/2019

\section{REFERENCES}

Alieksieienko, T. F. ( 2007). Sotsializatsiia osobystosti: mozhlyvosti y ryzyky. Kyiv : Ped. dumka.

Bыkov, A. K., Volokhatova, V. M. (2014). Formyrovanye sotsyalnыkh kompetentsyi, hotovnosty k samostoiatelnomu zhyzneustroistvu $\mathrm{u}$ vospytannykov detskykh ynternatnokh uchrezhdenyi. Moskva : YPKDSZN.

Bobak, O. (2012). Pidhotovka sotsialnoho pedahoha do orhanizatsii roboty z simieiu yak pervynnoho instytutu sotsializatsii dytyny. Aktualni pytannia humanitarnykh nauk, 3, 152-158.

Piesha, I. V. (2000). Sotsialne stanovlennia ditei $\mathrm{v}$ dytiachykh budynkakh simeinoho typu. (Avtoref. dys. ... kand. ped. nauk). Natsionalnyi ped. un-t im. M. P. Drahomanova, Kyiv.

Kozhna dytyna zrostaie ta vykhovuietsia $\mathrm{v}$ rodynakh abo $\mathrm{v}$ umovakh, maksymalno nablyzhenykh do simeinykh, u blahopoluchnomu, dobrozychlyvomu ta bezpechnomu seredovyshchi, de dbaiut pro potreby ta interesy ditei. Prohrama diialnosti Kabinetu Ministriv Ukrainy. (2019). Retrieved from https:// program.kmu.gov.ua/meta/kozna-ditinazrostae-ta-vihovuetsa-v-rodinah-abo-vumovah-maksimalno-nablizenih-dosimejnih-u-blagopolucnomudobroziclivomu-ta-bezpecnomuseredovisi-de-dbaut-pro-potrebi-tainteresi-ditej

Riul, V. O. (2013). Sotsializatsiia ditei trudovykh mihrantiv Zakarpattia. Uzhhorod : Vydavnytstvo FOP Breza A.E.

Stelmakhovych, M. H. (1996). Teoriia i praktyka ukrainskoho natsionalnoho vykhovannia. Ivano-Frankivsk : LileiaNV.

Pro deiaki pytannia zabezpechennia prav ta zakonnykh interesiv ditei-syrit, ditei, pozbavlenykh batkivskoho pikluvannia, rozvytku ta pidtrymky simeinykh form vykhovannia ditei. Ukaz Prezydenta Ukrainy. (2019). Retrieved from https://zakon.rada.gov.ua/go/721/ 2019

Стаття надійшла 20.03.2020 р. 